\title{
The Right to a Balanced and Healthful Ecology in the Legal Framework of the European Convention of Human Rights and Case Law of the Ecthr
}

\author{
El Derecho a una Ecología Equilibrada y \\ Saludable en el Marco Jurídico de la Convención \\ Europea de Derechos Humanos y Jurisprudencia del \\ TEDH
}

Elena Evgenyevna Gulyaeva*

\begin{abstract}
1 Introduction. 2 Positive state obligations on a healthy and sustainable environment under the convention provisions. 3 Admissibility criteria for complaints to the European Court of Human Rights in "environmental cases". 4 Overview of the European Court of Human Rights Jurisprudence on the protection of the rights of individuals and groups to complain for violations of their rights to a healthy and favorable environment. 4.1 Applications alleging exceeding standards of traffic and other noise. 4.2 Applications alleging industrial pollution. 4.3 Applications alleging negligence of the authorities resulting in environmental accidents. 4.4 Applications alleging waste pollution, odors or other types of interference. 4.5 Application alleging the authority's inaction resulting in violations of the applicants' health rights during nuclear and chemical testing (nuclear tests). 5 Conclusions. References.
\end{abstract}

\begin{abstract}
Objective: The author seeks to understand the content and legal guarantees of the right to sustainable, healthy and favorable environment in the jurisprudence of the European Court of Human Rights. The researcher seeks to list the case law of the ECtHR corresponding to environmental issues in order to define concrete aspects related to responsibility of the States for the climate change and global warming. The author

\footnotetext{
PhD, Associate Professor at International Law Department, Diplomatic Academy of the Russian Ministry of Foreign Affairs; Member of Russian Association of International Law, Member of European Association of International Law, Member of the Council for International Relations of the International Institute of Human Rights (IIDH -America), Member of Constitutional Council of Justice (Argentina); 119021, Moscow, Ostozhenka 53/2, Building 1. E-mail: <gulya-eva@yandex.ru>. ORCID: 0000-0001-8376-7212
} 
The right to a balanced and healthful ecology in the legal framework of the European Convention of Human Rights and case law of the ECtHR

analyzes new legal trends on the protection of the rights of individuals and groups to complain for violations of their rights to a healthy and favorable environment in the light of the European Convention on Human Rights. The article is focused on positive state obligations on a healthy and sustainable environment under the Convention provisions, Russian experience in eco-cases, admissibility criteria for complaints to the European Court of Human Rights in "environmental cases". The writer gives an overview of the ECtHR's legal positions on the right to a healthy and favorable (i.e. prosperous, clean, safe, quiet, calm, quality) environment by type of its pollution. The author considers the importance of facilitating the right to healthy environment according to the UN Sustainable Development Goals.

Methodology: The research uses general scientific and special cognitive techniques wherein legal analysis and synthesis, systemic, formal-legal, comparative-legal, historicallegal and dialectical methods are applied. The author applied a case study method to select the most recent and pilot cases of the ECtHR practice.

Results: The author founds out that despite the fact of a non-exhaustive list of the legal positions of the ECtHR concerning the environment effect on human life and health, there is a certain trend in Council of Europe towards an extended interpretation of the human right to healthy ecological situation responding to new challenges to the realization that right, such as, the decarbonization of industrial processes, right to light, right to fresh air, clean water and clean atmosphere, etc. The study concludes with an idea that right to sustainable, healthy and favorable right is a collective right. From the practical perspective, potentially group of individuals should complain to the international judicial institutions to the violation of this right. The importance of the protection of that right is increasing within the technological progress. The right to healthy environment imposes to the European States a legal obligation to ensure right to life, prohibition of torture, right to privacy, right to a fair trial, right to an effective remedy and prohibition of discrimination. The researcher also point out that cases of environmental rights violations are complicated in terms of preparing a complaint and processing by the ECtHR. Due to this fact, it is hard to do so with regard to the causal link between the acts (omission) of state agencies, the violation of environmental rights and the consequences that occurred. It is not clear from the text of the Convention which article directly should be applied.

Contributions: Following a review of the content, the author raised possible problems, strategies, suggestions and guidelines for the protection of the right to sustainable and healthy environment. The author concluded that near future new categories of legal cases related to the state responsibility for global warming and climate change will appear in international and national judicial system. The author encourages the 
complement to the international legal regulation of the protection of the right to healthy, sustainable and favorable ecology on universal and regional level.

Keywords: right to healthy and favorable environment; Convention for the Protection of Human Rights and Fundamental Freedoms of 1950 (further - Convention); European Court of Human Rights (further - ECHR, Court); environmental cases; ecological cases; eco-cases; human rights; human rights guarantee; violation of Convention provisions; positive obligation of states; margin of appreciation; admissibility criteria of complaint; Sustainable Development Goals (SDGs).

\section{RESUMEN}

El objetivo: El autor busca comprender el contenido y las garantías legales del derecho a un medio ambiente sostenible, saludable y favorable en la jurisprudencia del Tribunal Europeo de Derechos Humanos. El investigador busca enumerar la jurisprudencia del TEDH correspondiente a temas ambientales con el fin de definir aspectos concretos relacionados con la responsabilidad de los Estados por el cambio climático y el calentamiento global. El autor analiza las nuevas tendencias jurídicas sobre la protección de los derechos de las personas y los grupos a denunciar las violaciones de sus derechos a un medio ambiente sano y favorable a la luz del Convenio Europeo de Derechos Humanos. El artículo se centra en las obligaciones estatales positivas sobre un medio ambiente sano y sostenible en virtud de las disposiciones de la Convención, la experiencia rusa en casos ecológicos, los criterios de admisibilidad de las quejas ante el Tribunal Europeo de Derechos Humanos en "casos medioambientales". El autor ofrece una descripción general de las posiciones legales del TEDH sobre el derecho a un medio ambiente saludable y favorable (es decir, próspero, limpio, seguro, tranquilo, de calidad) por tipo de contaminación. El autor considera la importancia de facilitar el derecho a un medio ambiente saludable de acuerdo con los Objetivos de Desarrollo Sostenible de la ONU.

La metodología: La investigación utiliza técnicas científicas generales y cognitivas especiales en las que se aplican métodos de análisis y síntesis legal, sistémico, formallegal, comparado-legal, histórico-legal y dialéctico. El autor aplicó un método de estudio de caso para seleccionar los casos piloto más recientes de la práctica del TEDH.

Los resultados: El autor descubre que, a pesar de que existe una lista no exhaustiva de las posiciones legales del TEDH sobre el efecto del medio ambiente en la vida y la salud humanas, existe una cierta tendencia en el Consejo de Europa hacia una interpretación ampliada del derecho humano a la salud. situación ecológica respondiendo a nuevos desafíos para la realización de ese derecho, entre otros, los procesos de descarbonización, derecho a la luz, aire puro, agua dulce y atmósfera limpia, etc. El estudio concluye con la 
The right to a balanced and healthful ecology in the legal framework of the European Convention of Human Rights and case law of the ECtHR

idea de que el derecho a un derecho sostenible, saludable y favorable es un derecho colectivo y un grupo de personas deben denunciar la violación de este derecho. La importancia de la protección de ese derecho está aumentando dentro del progreso tecnológico. El derecho a un medio ambiente sano impone a los Estados europeos la obligación legal de garantizar el derecho a la vida, la prohibición de la tortura, el derecho a la intimidad, el derecho a un juicio justo, el derecho a un recurso efectivo y la prohibición de la discriminación. El investigador también señala que los casos de violaciones a los derechos ambientales son complicados en cuanto a preparar una denuncia y tramitarla ante el TEDH. Debido a este hecho, es difícil hacerlo con respecto a la relación causal entre los actos (omisión) de los organismos estatales, la violación de los derechos ambientales y las consecuencias ocurridas. No se desprende claramente del texto de la Convención qué artículo debe aplicarse directamente.

Los contribuciones: Tras una revisión del contenido, el autor planteó posibles problemas, estrategias, sugerencias y pautas para la protección del derecho al medio ambiente sostenible y saludable. El autor llegó a la conclusión de que en un futuro próximo aparecerán en el sistema judicial nacional e internacional nuevas categorías de casos legales relacionados con la responsabilidad estatal por el calentamiento global y el cambio climático. El autor alienta el complemento a la normativa legal internacional de la protección del derecho a una ecología sana, sostenible y favorable a nivel universal y regional.

Palabras clave: derecho a un medio ambiente sano y favorable; Convenio para la Protección de los Derechos Humanos y Libertades Fundamentales de 1950 (Convenio); Tribunal Europeo de Derechos Humanos (CEDH, Tribunal); casos ambientales; casos ecológicos; casos ecológicos; derechos humanos; garantía de derechos humanos; violación de disposiciones de la Convención; obligación positiva de los estados; margen de apreciación;criterios de admisibilidad de la denuncia; Objetivos de Desarrollo Sostenible (ODS).

\section{INTRODUCTION}

In the speech on 24 October 2020 at the United Nations 75th anniversary celebrations, UN Secretary General António Guterres declared 2021 to be the "Ecological Decade" worldwide (GUTERRES, 2020). Meanwhile, EU policies aim to protect the environment and biodiversity, minimize risks to human health, and promote the transition to a circular economy ${ }^{1}$. In this article, the author seeks to analyze the

${ }^{1}$ Official website of EU towards EU environmental priorities and targets. URL: https://ec.europa.eu/environment/index_en 
world's highest environmental standards in European legal system.

Currently, the legal framework for long-term environmental cooperation among states is most fully codified informally ${ }^{2}$. It has to be emphasized, however, that environmental rights are considered in the legal doctrine as a modern generations of human rights (VASAK, 1973). The human right to a healthy and clean environment (MAY; DALY, 2019; TURNER et al., 2019; KNOX; PEJAN, 2018; SOLNTSEV, 2015) is an inalienable right. A new stage in the struggle for clean Earth was the elaboration and signing of the Paris Agreement and the Kyoto Protocol (UNITED NATIONS TREATY COLLECTION, 2015) ${ }^{3}$.

International environmental law (VIÑULES, 2020; GAETA; VIÑUALES; ZAPPALÁ, 2020; BHUTA, 2016), despite its growing importance, is difficult to access because of its technical nature and its extreme diversity. Eminent Professor Jorge E. Viñuale mentioned (DUPUY, 2015; DUPUY; VIÑUALES, 2015) that «nuclear energy, the depletion of the ozone layer, climate change, the protection of wetlands or biodiversity, trade in endangered species, regulation of persistent organic pollutants or hazardous wastes, and many more gives the impression of an exotic material, with a sparse structure, making access to this area and its assimilation very difficult».

The Russian Federation is a Party to the Paris Agreement, the UN Framework Convention on Climate Change, its Kyoto Protocol and treaties on the ozone layer protection ${ }^{4}$. The climate policy in our country is being implemented in accordance with the Climate Doctrine of the Russian Federation approved by 17 December 2009 Russian Presidential Decree No. 8615. In the first period of the Kyoto Protocol operation, Russia has not exceeded the established level of greenhouse gas emission by 100 per cent of the 1990. Until 2020, the target for limiting greenhouse gas emissions was set by Presidential Decree No. 752 of September 30, 2013 and is no more than 75 per cent of the 1990 level.

\footnotetext{
${ }^{2}$ Draft International Covenant on Environment and Development - Implementing Sustainability Fifth Edition: Updated Text. 2015. URL: https://sustainabledevelopment.un.org/; New Delhi Declaration on the Principles of International Law Related to Sustainable Development of 2002. URL: https://www.ecolex.org/details/literature/new-delhi-declaration-of-principles-of-international-lawrelating-to sustainable-development-mon-070850/

${ }^{3}$ The Paris Climate Agreement was adopted at the World Climate Conference in 2015. Currently there are 195 Contracting Parties to this international treaty, and 189 countries, including Russia, have ratified the treaty.

${ }^{4}$ On February 16, 2005, the Kyoto Protocol to the 1992 United Nations Framework Convention on Climate Change came into force, addressing the issue of global warming. It requires industrialized countries to reduce their combined emissions of six major greenhouse gases during the five-year period from 2008 to 2012 below the levels that existed in 1990. By the time the Protocol entered into force, more than 190 countries had ratified it. URL: https://legal.un.org/avl/ha/ccc/ccc.html

${ }^{5}$ Presidential Decree of 17.12.2009 № 861-rp "On Climate Doctrine of Russian Federation". URL: http://www.consultant.ru/document/cons_doc_LAW_94992/
} 
The right to a balanced and healthful ecology in the legal framework of the European Convention of Human Rights and case law of the ECtHR

One of the key markers state regulation field of harmful emissions is the so-called Intended Nationally Determined Contribution (hereinafter - INDC). The Russian Federation submitted a first report (INDC) under the Paris Agreement. The target set by Russia contributes to the global temperature goal, as by 2030 , the cumulative reduction in Russian greenhouse gas emissions since 1990 will exceed 55 billion tons of carbon dioxide equivalent. The Decree of the President of Russia states that "economic-wide greenhouse gas emissions will be limited by 2030 to 70 per cent of the 1990 level with due regard for the need of sustainable socio-economic development and maximum consideration of the absorptive capacity of forests and other natural ecosystems" ${ }^{6}$. Russia is one of the few countries that has exceeded their commitments under the Kyoto Protocol in its first period of operation, and since 2013 has voluntarily set increasingly ambitious targets to reduce greenhouse gas emissions?

It is worth looking at recent reform proposals, such as the Global Pact for the Environment initiative proposed by France at the United Nations. The Global Pact for the Environment ${ }^{8}$ is a proposed international treaty that aims to recognize the fundamental principles (DUVIC-PAOLI, 2018, 2019, 2012) of environmental law on a global scale. An international group of lawyers devised a preliminary draft in 2017. It has been under discussion at the United Nations since United Nations General Assembly Resolution 72/277 of 10 May 2018, entitled "Towards a Global Pact for the Environment". A Political Declaration will be adopted on the matter in 2022 at an international conference. Both Russian and French presidents have identified the environmental question as a priority within the framework of the "Trianon Dialogues".

The measures and efforts that the government has undertaken are not, however, sufficient to fully attain the objectives of environment protection and human rights violations are not uncommon in this area. The Convention for the Protection of Human Rights is one of the mechanisms for effectively protecting the fundamental freedoms of 1950 that forms the framework of the European Court of Human Rights.

Although there are no provisions in the Convention ${ }^{10}$ or its additional protocols that are directly relevant to the right to a healthy and ecologically balanced environment, the European Court of Human Rights, in its case law and that of the European Commission, has recognized that certain types of environmental degradation

\footnotetext{
${ }^{6}$ Decree of the President of the Russian Federation "On reduction of greenhouse gas emissions" № 666 of November 4, 2020. URL: http://www.kremlin.ru/acts/bank/45990

${ }^{7}$ URL: https://www.economy.gov.ru/material/news/ Russia reported about the first Intended Nationally Determined Contribution under the Paris Agreement.html

${ }^{8}$ The Global Pact for the Environment project. URL: https://globalpactenvironment.org/en/

${ }^{9}$ Trianon Dialogues. URL: https://dialogue-trianon.ru/

${ }^{10}$ Convention for the Protection of Human Rights and Fundamental Freedoms of 1950. URL: https://www.echr.coe.int/Documents/Collection_Convention_1950_ENG.pdf
} 
with grave consequences for individuals or the failure of public authorities to provide information on environmental risks individuals are exposed to, may constitute a violation of certain rights protected by the Convention: right to life, prohibition of torture, right to privacy, family or property. According to the official document of Council of Europe, the broad definition (COUNCIL OF EUROPE, 2006) ${ }^{11}$ of "Environment" can be found in the Convention on Civil Liability for Damage Resulting from Activities Dangerous to the Environment (Lugano, 21 June 1993) which provides in its Article 2 (10): "Environment" includes:

- natural resources both abiotic and biotic, such as air, water, soil, fauna and flora and the interaction between the same factors;

- property which forms part of the cultural heritage; and

- the characteristic aspects of the landscape.

Regarding the environmental protection, the European Charter of Fundamental Rights $^{12}$ stipulates that a high degree of environmental protection and the improvement of environmental quality must be engraved into EU policies and guaranteed under the sustainable development principle ${ }^{13}$. Now this concept has even expanded to include

${ }^{11}$ Manual on Human Rights and the Environment. Council of Europe Publishing. Strasbourg, 2006.
URL: https://www.echr.coe.int/Documents/Pub_coe_Environment_2012_ENG.pdf
${ }^{12}$ European Charter of Fundamental Rights of $2000 . \quad$ URL: https://www.europarl.europa.eu/charter/pdf/text_en.pdf

${ }^{13}$ Among the 17 UN Sustainable Development Goals (SDGs 2030), the environmental issues in Goals 3, $6,12,13,14,15,16,17$ should be highlighted. For example, "Goal 3: Good Health and Well-Being" is as follows: "Ensure healthy lifestyles and promote well-being for all at all ages", in particular, it is necessary to reduce morbidity and mortality from hazardous chemicals and pollution // UN Sustainable Development Goals - 2030 // https://sdgs.un.org/goals It should be noted that the principle of sustainable development is firmly embedded in the conceptual apparatus of international public law. For example, in one of the decisions of the International Court of Justice, Judge C.G. Weeramantry, in his dissenting opinion to the judgment in the Gabcikovo Nadymaroch case, called it a new fundamental principle of modern international law. See: Case Concerning the GabčikovoNagymaros Project (Hungary/Slovakia) (1997), I.C.J. Rep. 7), Advisory Opinion on the Legality of the Use by a State of Nuclear Weapons in Armed Conflict, Advisory Opinion, [1996] ICJ Rep. 226 at 438 and Certain Phosphate Lands in Nauru (Nauru/Australia) (1993), I.C.J. Rep. 322. See also United States - Import Prohibition of Certain Shrimp and Shrimp Products, 20 September, 1999, WTO Doc.WT/DS58/AB/R (Appellate Body Report) and LCB v. United Kingdom of ECHR. (1998) European Court of Human Rights Reports 1998-III. Sustainable Development Principles in the Decisions of International Courts and Tribunals: 1992-2012 // Marie-Claire Cordonier Segger (Editor), Yolanda Saito (Editor), Judge C.G. Weeramantry (Editor). 2017. P.884. The Sustainable Development Goals are a call to action and aim to improve the well-being and protection of our planet. States recognize that measures to eradicate poverty must go hand in hand with efforts to combat climate change and protect the environment. The indicators are divided into main groups: indicators of the social aspects of sustainable development; indicators of the economic aspects of sustainable development; indicators of the environmental aspects of sustainable development (including characteristics of water, land, atmosphere, other natural resources, and waste); indicators of the institutional aspects of sustainable development (programming and policy planning, scientific development, international legal instruments, information provision, strengthening the role of key population groups). See, Dworkin Ronald Policies and Principles. Praha, Oikoymenh, 2001. In this paper, Ronald Dworkin highlights the distinction between principles of law and legal policy. As Professor Dworkin notes, "arguments in favor of principles are arguments aimed at establishing the 
The right to a balanced and healthful ecology in the legal framework of the European Convention of Human Rights and case law of the ECtHR

most aspects of human life, the natural environment and the use of natural resources. This expansion has taken place since the development of the Agenda 2030 and the UN Sustainable Development Goals ${ }^{14}$. While sustainable development also includes economic and social issues (including human rights), the environment has always been key. The scientific research on which policies and laws are based is increasingly addressing climate change and biodiversity issues.

Sustainable development is an overarching objective for the EU, which is committed to a 'high level of protection and improvement of the quality of the environment' (Article 3 of the Treaty on European Union) ${ }^{15}$. In the quest to be the first climate-friendly continent by 2050 within a European "green agreement", EU states have been looking for the potential of adopting a European climate law designed to translate political statements into legal obligations and investment incentives. Decarbonization processes ${ }^{16}$ (i.e., reducing $\mathrm{CO} 2$ emissions) are being prepared, with fossil fuel use, electrification and energy systems being adjusted to ensure sustainable growth and environmental sustainability, so that the EU can become a leader in green technology and ensure a sustainable environment. All EU environmental strategies and actions plans aim to contribute to the objectives of the European Green Deal ${ }^{17}$. The EU legal system provides special regulations in the following areas:

- to improve air quality and reduce air pollution;

- to ensure chemicals are safe, for health and the environment;

- to a circular economy with a focus on green growth;

- to make industry more sustainable and reduce industrial emissions;

- to protect Europe's coasts, seas and oceans;

- EU action on environmental conservation and protection;

- to reduce environmental noise pollution;

- EU action on plastic production and pollution to contribute to a circular economy;

- EU action for the sustainable use of soil and land;

rights of individuals; and arguments in favor of politics are arguments aimed at establishing a collective goal."

${ }^{14}$ UN General Assembly: Resolution adopted by the General Assembly on 25 September 2015 "Transforming our world: the 2030 Agenda for Sustainable Development". URL: https://undocs.org/A/RES/70/1

${ }^{15}$ Environment and climate change. URL: https://eur-lex.europa.eu/summary/chapter/20.html

${ }^{16}$ Note: The main areas of decarbonization of energy systems are electrification, decarbonization of power generation capacity, and energy efficiency. The goal of decarbonization is to replace systems based on fossil fuels with electricity generated using low-carbon resources, such as renewable energy sources. URL: https://neftegaz.ru/tech-library/energoresursy-toplivo/141763-vozobnovlyaemyeistochniki-energii-vie/

${ }^{17}$ Official website of EU towards EU environmental priorities and targets. URL: https://ec.europa.eu/environment/index_en

110 - R. Opin. Jur., Fortaleza, ano 20, n. 33, p.103-134, jan./abr. 2022 
- to promote the sustainability of European cities;

- EU action on waste management, treatment and recycling;

- EU action on water issues, to protect water resources.

Handling complaints of violations of the right to a healthy and favorable environment (hereinafter "environmental cases") (TRIKOZ; GULYAEVA, 2021; ANISIMOV; GULYAEVA, 2021), the European Court of Human Rights identifies categories of cases in which the poor environment adversely effects the health of citizens. As the Court notes in its jurisprudence, there is a close relationship between environmental protection and the human right to health. There is no explicit right to a clean and secure environment in the Convention. However, if a person is directly and seriously affected by environmental pollution, this may entail a violation of the rights in Articles 2, 3 or 8 of the Convention ${ }^{18}$. A well-founded complaint is recognized if the environmental hazard reaches a level that significantly limits housing and tenure rights, violates the right to private and family life ${ }^{19}$. The assessment of this minimum level is relative and depends on all the circumstances of the case, such as the intensity and duration of the violation, as well as its physical or mental impact on health or life quality $^{20}$. Article 8 applies in environmental cases where the pollution is directly attributable to the State or where State liability arises because of the failure to regulate the private sector properly.

\section{POSITIVE STATE OBLIGATIONS ON A HEALTHY AND SUSTAINABLE ENVIRONMENT UNDER THE CONVENTION PROVISIONS}

Considering cases relating to the right to a healthy and favorable environment protection, the European Court of Human Rights relies on the 1950 Convention for the Protection of Human Rights and Fundamental Freedoms (hereinafter the Convention, ECHR). Article 8 of the Convention is used much more frequently than the others ${ }^{21}$, there is also little practice of using Article 2 (right to life) ${ }^{22}$ and Article 3 (prohibition of torture) of the Convention, as well as Article 1 of Protocol 1 (right to

\footnotetext{
${ }^{18}$ Application no. 36022/97, Hatton and Others v. the United Kingdom, ECHR Judgment of 08 July 2003.

${ }^{19}$ Application no. 16798/90, López Ostra v. Spain, ECHR Judgment of 09 December 1994, § 51.

${ }^{20}$ Application no. 55723/00, Fadeyeva v. Russia, ECHR Judgment of 09 June 2005, § 69.

${ }^{21}$ Application no. 36022/97, Hatton and Others v. the United Kingdom, ECHR Judgment of 08 July 2003; Application no. 16798/90, López Ostra v. Spain, ECHR Judgment of 09 December 1994; Application no. 55723/00, Fadeyeva v. Russia, ECHR Judgment of 09 June 2005.

${ }^{22}$ Application no. 14/1997/798/1001, L.C.B. v. The United Kingdom, ECHR Judgment of 9 June 1998; Application no. 48939/99, Önerylldı v. Turkey, ECHR Judgment of 30 November 2004; Applications nos. 67667/09, 44092/12 and 56717/12, Budayeva and Others v. Russia, ECHR Judgment of 20 June 2017; Applications nos. 17423/05, 20534/05, 20678/05, 23263/05, 24283/05 and 35673/05, Kolyadenko and Others v. Russia, ECHR Judgment of 09 July 2012.
} 
The right to a balanced and healthful ecology in the legal framework of the European Convention of Human Rights and case law of the ECtHR

privacy), Article 6 (right to a fair trial), Article 13 (right to an effective remedy) and Article 14 (prohibition of discrimination).

As it is normal ECtHR practice, the Convention imposes on States parties along with negative obligations (obligation to refrain from acts violating the guaranteed rights), certain positive obligations, which are the consequence of the Convention Article 1, enshrining the obligation of the High Contracting Parties "to ensure to everyone ... the rights and freedoms set forth in ... the Convention”. To a greater or lesser extent, certain positive obligations are inherent in every right guaranteed by the Convention and require the State to establish certain legislative standards to secure this or that right, enabling the design and operation of institutional structures (in particular, law enforcement bodies with the necessary competence), etc.

In cases involving violations of such fundamental rights and freedoms as the right to life (Article 2 of the Convention) and the right to freedom from torture (Article 3 of the Convention), the Court places heavy emphasis on the analysis of compliance with positive obligations of a procedural nature, which include the duty of the State to investigate effectively alleged violations of such rights (GOMIEN, 2005, p. 16-19). The mere fact of a breach of a procedural obligation, in the view of the ECtHR, already indicates a violation of the right in question, and the practice in cases against Russia in particular is quite revealing in this regard ${ }^{23}$.

The principles relied upon by the Court in "environmental cases" are broadly similar. ${ }^{24}$ For example, in terms of positive obligations ${ }^{25}$, the State must take reasonable and appropriate measures to protect the rights of applicants in the event of undue interference by a public authority. In both contexts, consideration must be given to the fair balance to be struck between the competing interests of the individual and society as a whole; and in both contexts, the State enjoys a certain margin of appreciation ${ }^{26}$ in

\footnotetext{
${ }^{23}$ See, for example: Application no. 60272/00, Estamirov and others v. Russia, ECHR Judgment of 12 October 2006, § 118; Applications nos. 57942/00 and 57945/00, Khashiev and Akayeva v. Russia, ECHR Judgment of 24 February 2005, § 153; Application no. 77617/01, Mikheyev v. Russia, ECHR Judgment of 26 January 2006, § 104.

${ }^{24}$ Professor A.Y. Kapustin formulates such a general rule as follows: "the obligations assumed by the High Contracting Parties under the Convention apply to subjects residing or domiciled in their respective territories. See: Kapustin A.Y. Political-legal consequences of the EU policy reformatting on the international scene after the Reform Treaty comes into force. // What internal and external EU policies will be after Lisbon Treaty coming into force (Materials of the international conference, held in MGIMO (U) of MFA of Russia, February 22, 2008). M., 2008. C. 111.

${ }^{25} \mathrm{On}$ the category of "positive obligations" in relation to the Convention, see, in particular: Tumanov (2001). European Court of Human Rights: Overview of the Organization and Activities, Moscow, 2001, p. 109-111; The right to life, prohibition of torture and inhuman or degrading treatment or punishment: European standards, Russian legislation and law-enforcement practice (CHURKINA, L. M.; BELYAEV, 2005, p. 24-37); Conforti (2004, p. 129-137); Starmer (2001, p. 139-159).

${ }^{26}$ State discretion is the right of a State to interfere with a right or freedom guaranteed by the Convention, based on the norms of the Convention, limited by the need to respect the principle of proportionality and with the primary objective of effectively ensuring the human rights and freedoms
} 
determining the steps to be taken to ensure compliance with the Convention. Some cases in this area have been dealt with under Article 2 and the positive obligation to take all necessary steps to preserve life $^{27}$. In the case of hazardous activities of enterprises, particular attention shall be paid to the rules relating to the specificity of the activities in question, especially with regard to the level of potential risk to life. Specific rules should regulate the licensing, establishment, operation, safety and supervision of potentially harmful industries and mandatory implementation of practical measures by all relevant stakeholders to ensure the effective protection of citizens whose lives may be at foreseeable risk $^{28}$. As for preventive measures, special attention should be paid to the right of the public to information, as established by the case law of the European Court of Human Rights. Regulations should also provide for the necessary procedures, taking into account the technical aspects of the activities in question, to identify weaknesses in the processes and any mistakes made by those responsible at different levels ${ }^{29}$. Where the State is required to take positive steps, the choice of means, as previously stated, is within its discretion.

Thus, in the case of López Ostra v. Spain ${ }^{30}$ concerned the harmful effects caused by noise and smell from a recycling plant, the ECtHR found in 1995 that "major environmental contamination can have adverse effects on citizens and prevent them from enjoying their homes, which would also be to the detriment of their private and family life, even if their health has not been seriously endangered". The Court, based on

enshrined in the Convention, if there are reasonable and sufficient grounds for doing so under domestic law. Moreover, States restrict rights and freedoms only in accordance with the norms of domestic law, but the content of such norms is the freedom of discretion (although, in this case, of course, international obligations of the State must be taken into account). In the legal positions of the ECtHR, the principle of the freedom of discretion of states ("margin of appreciation") is elaborated in detail. In Russian science this principle is called differently: "freedom of discretion", "margin of appreciation", "margin of appreciation". At the same time, its translation as "freedom of discretion" is, in our opinion, the most acceptable, since the essence of the principle is to leave the appropriate freedom to the state. The word "margin" only emphasizes that this freedom is not unlimited, to establish its limits, however, are called for other legal structures developed in the practice of the ECtHR, such as the principles of legality, reasonableness, proportionality. Thus, in relation to the system of human rights protection established by the Convention, the term "margin of appreciation" can be considered as legal, since it was enshrined in the legal positions of the ECtHR, which are of a legal nature. See: Lipkina (2008, p. 8). Legal positions of the European Court of Human Rights The case of the United Kingdom of Great Britain and Northern Ireland in the case of the United Kingdom of Great Britain and Northern Ireland in the case of the United Kingdom of Great Britain and Northern Ireland in the case of the United Kingdom of Great Britain and Northern Ireland. Candidate of Legal Sciences: 12.00.10.

${ }^{27}$ Application no. 14/1997/798/1001, L.C.B. v. The United Kingdom, ECHR Judgment of 9 June 1998 , § 36.

${ }^{28}$ Application no. 48939/99, Öneryldız v. Turkey, ECHR Judgment of 30 November 2004, § 90.

29 Application no. 67667/09, 44092/12 and 56717/12, Budayeva and Others v. Russia, ECHR Judgment of 20 June 2017, § 132.

${ }^{30}$ Application no. 16798/90, López Ostra v. Spain, ECHR Judgment of 09 December 1994, § 51. URL: http://hudoc.echr.coe.int/rus?i=001-57905 
The right to a balanced and healthful ecology in the legal framework of the European Convention of Human Rights and case law of the ECtHR

Article 8 of the Convention, ordered the Spanish authorities to pay four million pesetas in damages to the applicant. The ECtHR found a violation of Article 8 of the Convention in the State's failure to strike a fair balance between the interests of the economic well-being of the town and the applicant's effective exercise of her right to respect for her home and her private and family life.

Article 8 of the European Convention on Human Rights, which enshrines the right to respect for private and family life, the inviolability of home and secrecy of correspondence, was also applied by the ECtHR in 2006 on the case of "Giacomelliv. Italy" ${ }^{\prime 1}$ concerning the activities of a toxic industrial waste storage and processing plant. The Court emphasized that "violations of the right to inviolability of the home are not limited to specific physical violations, such as illegal entry into a person's home, but also include such violations as noise pollution ${ }^{32}$, pollution from industrial activities ${ }^{33}$, environmental accidents ${ }^{34}$, nuclear tests ${ }^{35}$, pollutant emissions ${ }^{36}$, unpleasant odors or other interference. ${ }^{37}$

The Court stated that a serious infringement could be the consequence of depriving a person of the inviolability of his or her home if it prevents him from enjoying the facilities.

It is rather remarkable that in the case "Giacomelli v. Italy" 38 the Court has generalized some of its previous decisions based on art. 8 relating to environment: in the

\footnotetext{
${ }^{31}$ Application no. 59909/00, Giacomelli v.Italy, ECHR Judgement of 02 November 2006.

32 Application no. 50474/08, Bor v. Hungary, ECHR Judgment of 18 September 2013; Application no. 2345/06, Deés v. Hungary, ECHR Judgment of 09 November 2010; Application no. 38182/03, Grimkovskaya v. Ukraine, ECHR Judgment of 21 July 2011; Application no. 17840/06, Yevgeniy Dmitriyev v. Russia, ECHR Judgment of 1 December 2020.

${ }^{33}$ Application no. 16798/90, López Ostra v. Spain, ECHR Judgment of 09 December 1994; Application no. 55723/00, Fadeyeva v. Russia, ECHR Judgment of 09 June 2005; Applications nos. 53157/99, 53247/99 and 56850/00, Ledyayeva, Dobrokhotova, Zolotareva and Romashina v. Russia ECHR Judgment of 26 October 2006; Application no. 30499/03, Dubetska and Others v. Ukraine, ECHR Judgment of 10 February 2011.

${ }^{34}$ Application no. 14967/89, Guerra and Others v Italy, ECHR Judgment of 19 February 1998; Application no. 67021/01, Tătar v. Romania, ECHR Judgment of 27 January 2009; Application no. 48939/99, Önerylldı v. Turkey, ECHR Judgment of 30 November 2004; Application no. 67667/09, 44092/12 and 56717/12, Budayeva and Others v. Russia, ECHR Judgment of 20 June 2017.

${ }^{35}$ Application nos. 21825/93, 23414/94, McGinley \& Egan v. the United Kingdom, ECHR Judgment of 9 June 1998; Application no. 14/1997/798/1001, L.C.B. v. The United Kingdom, ECHR Judgment of 9 June 1998; Application no. 32555/96, Roche v. The United Kingdom, ECHR Judgment of 19 October 2005.

${ }^{36}$ Application no. 39951/08, Brânduşe v. Romania, ECHR Judgment of 27 October 2015; Application no. 30765/08, Di Sarno and Others v. Italy, ECHR Judgment of 10 January 2012; Application no. 59909/00, Giacomelli v. Italy, ECHR Judgment of O2 November 2006.

${ }^{37}$ Application no. 4143/02, Moreno Gómez v. Spain, ECHR Judgment of 16 November 2004; Application no. 61260/08, Oluić v. Croatia, ECHR Judgment of 20 August 2010; Application no. 43449/02, Mileva and Others v. Bulgaria, ECHR Judgment of 25 February 2011; Application no. 3356/15, Zammit Maempel and Others v. Malta, ECHR Judgment of 10 October 2017.

${ }^{38}$ Application no. 59909/00, Giacomelli v.Italy, ECHR Judgement of 02 November 2006.
} 
"Powell and Rainer v. United Kingdom" 39 the European Court of Justice declared article 8 of the Convention applicable since it was held that the quality of applicant's private life and enjoyment of the household amenities were disturbed by airplane noise from Heathrow airport. In the case "Guerra and Others $v$ Italy" direct exposure of applicants to toxic emissions means that article 8 of the Convention is applicable in their case.

In the case "Dubetska and Others v. Ukraine" 41 involving 11 individuals, it was noted that "the right guaranteed by Article 8 of the Convention is violated by the environmental contamination caused by a State-owned mine and factory (their waste specifically) and by the failure of the State to fulfill its positive obligation to ensure the safety of hazardous industrial activities".

In 2002, the ECHR had ruled on the application of art. 2 of the Convention in a case "Öneryıldiz v. Turkey" 42 . The applicant claimed that as a result of the state negligence in the methane explosion at the landfill on 28 April 1993, nine members of his family had died. The Court regarded the case, under Article 2 of the Convention, as a violation of the right to life resulting from the failure of the State authorities to comply with their obligations under the Environmental Protection Act and the Solid Waste Regulation, which had caused the subsequent explosion and the deaths of many people.

The pilot case of "Grimkovskaya v. Ukraine" 43 was the platform to address some real issues. This process has set a meaningful precedent that can potentially be used by future applicants. The complainant, invoking a violation of Article 8 of the Convention, complained about the noise, vibration and pollution generated by traffic on the freeway near her home. According to the complainant, as corroborated by the results of the tests, the levels were several times higher than the permitted levels. The plaintiff developed health problems and the vibrations were destroying her home. In finding in favor of the plaintiff, the ECHR noted the absence of sufficient measures on the part of state authorities to control and reduce the level of pollution. It also noted the lack of proper information to citizens prior to the construction of the freeway, and the lack of citizens' access and participation in the decision-making process regarding the implementation of the project. The ECtHR upheld the complaint, awarding compensation for moral damages, but pointed out that the focus of the judgment was predominantly on the violations in the decision to build the freeway and in the implementation of the project, rather than on the consequences and their elimination.

\footnotetext{
${ }^{39}$ Application no. 9310/81, Powell and Rainer v. United Kingdom, ECHR Judgment of 21 February 1990.

${ }^{40}$ Application no14967/89, Guerra and Others v Italy, ECHR Judgement of 19 February 1998.

${ }^{41}$ Application no. 30499/03, Dubetska and Others v. Ukraine, ECHR Judgment of 10 February 2011.

${ }^{42}$ Application no. 48939/99, Önerylldız v. Turkey, ECHR Judgment of 30 November 2004.

${ }^{43}$ Application no. 38182/03, Grimkovskaya v. Ukraine, ECHR Judgment of 21 July 2011.
} 
The right to a balanced and healthful ecology in the legal framework of the European Convention of Human Rights and case law of the ECtHR

Therefore, the fact that the State did not provide the applicant with a new dwelling and did not compensate for the material damage cannot be considered a violation of Article 8 of the Convention.

Let us to refer to the decisions of the Court on the "environmental" cases against Russia $^{44}$. They were related mainly to plant operation ${ }^{45}$ and excessive atmospheric emissions $^{46}$, as well as to the consequences of the Chernobyl nuclear power plant disaster ${ }^{47}$.

In the case of "Fadeyeva v. Russia"48, the applicant claimed a violation of her rights under Art. 8 of the Convention since she lived approximately 450 meters from the largest steel mill in Russia and the pollution had caused serious damage to her health and well-being. The ECtHR found that for a considerable length of time the concentration of various toxic elements in the air near the claimant's house significantly exceeded the required standards, the Court found a violation of Article 8 of the Convention and ordered Russia to pay six thousand euros in damages.

Industrial accidents can cause a deterioration in the health of the local population, and in such circumstances, the state has a positive obligation to effectively eliminate the consequences of such events. In 2002, the ECtHR considered the complaint "Burdov v. Russia" ${ }^{\text {". }}$. The applicant had not directly claimed a violation of Article 8 of the Convention, but the connection of his case and the right to a healthy environment is clear. The applicant was a liquidator of the consequences of the Chernobyl Nuclear Power Plant explosion, where he had been forcibly sent as a member of armed forces and suffered from excessive exposure to radiation. He appealed to the ECHR because the decisions of the Russian courts about fair reparation had not been enforced for an unreasonably long period of time (1997-2001). The judges unanimously found a violation of the right to a fair trial and ordered the payment of 3,000 euros in damages. It was also recommended that Russia review laws inconsistent with international conventions signed by the state and pay money to Chernobyl liquidators

\footnotetext{
${ }^{44}$ Ecological Doctrine of the Russian Federation approved by decree of the Government of the Russian Federation on August 31, 2002 № 1225-r. Appendix 1 to Chapter 1. Key policy documents defining priorities, goals, objectives and mechanisms of their achievement for the economic, social and environmental component of sustainable development, covering the areas of sustainable development goals of the 2030 Agenda. The strategic goal of the state policy in the field of ecology is the conservation of natural systems, maintaining their integrity and life-supporting functions for the sustainable development of society, improving the quality of life, improving public health and the demographic situation, ensuring environmental security of the country.

${ }^{45}$ Application no. 55723/00, Fadeyeva v. Russia, Judgment of ECHR of 09 June 2005.

${ }^{46}$ Applications nos. 53157/99, 53247/99 and 56850/00, Ledyayeva, Dobrokhotova, Zolotareva and Romashina v. Russia ECHR Judgment of 26 October 2006.

${ }^{47}$ Application no. 59498/00, Burdov v. Russia, ECHR Judgment of 7 May 2002.

${ }^{48}$ Application no. 55723/00, Fadeyeva v. Russia, Judgment of ECHR of 09 June 2005.

${ }^{49}$ Application no. 59498/00, Burdov v. Russia, ECHR Judgment of 7 May 2002.
} 
without citing their deficiencies. This case became a pilot in the case law of the European Court of Human Rights.

In my opinion, the case "Malinowski v. Russia"50 (2005) is also noteworthy. The applicant complained about the continuous failure to enforce the decisions of the Russian courts. In clear violation of domestic law (specifically the Russian Federation Law on Social Protection of Citizens Injured During the Chernobyl Accident, which stipulates that the victims of the Chernobyl accident shall be provided with social housing within three months of the date of application) Malinowski was not provided with housing for a long time. In fact, from 1999 to 2004 the applicant and his family lived in an apartment with inadequate housing conditions. In 2001, the ECHR recognized I. M. Malinovsky's right to an apartment, but he did not get a warrant for it until 2004. As a result, the Court, as in the A.T. Burdov case, found a violation of Article 6 of the Convention and awarded a sum of 3,000 euros in damages.

These precedents only indirectly affect the right to a favorable environment: the applicants were persons affected by the adverse effects of the radiation however, their claims were caused by a violation of the right to a fair trial (Article 6 of the ECHR) ${ }^{51}$, which includes the right to a prompt hearing. It can be said that such ECtHR decisions encourage Russia and other states to abide by the applicable internal regulations on compensatory provisions for damage caused by adverse environmental conditions within a reasonable time.

\section{ADMISSIBILITY CRITERIA FOR COMPLAINTS TO THE EUROPEAN COURT OF HUMAN RIGHTS IN “ENVIRONMENTAL CASES”}

The case law of the European Court of Human Rights shows the growing interest of applicants in the protection of rights related to the environmental quality. The absence in the ECHR of an explicit reference to the right to a healthy and favorable environment is by no means an obstacle for the consideration of cases and rendering decisions mostly based on Article 2 (right to life), Article 3 (prohibition of torture), Article 6 (fair trial), Article 8 (right to respect for private and family life, inviolability of home), Article 13 (right to an effective remedy) and Article 14 (prohibition of discrimination). Such jurisprudence of the European Court of Human Rights, in our view, speaks volumes to the fact that the right to a favorable environment is a complex legal entity, the violation of which is not always and not entirely related to the violation of the right to life and health.

\footnotetext{
${ }^{50}$ Application no. 41302/02, Malinowski v. Russia, ECHR Judgment of 7 July 2005.

${ }^{51}$ Application no. 63973/00, Androsov v. Russia, ECHR Judgment of 6 of October 2005; Application no. 27440/03, Finkov v. Russia, ECHR Judgment of 8 October 2009.
} 
The right to a balanced and healthful ecology in the legal framework of the European Convention of Human Rights and case law of the ECtHR

Procedural aspect with regard to the handling of complaints by the ECtHR of interference with the right to a favorable environment is revealed through the Court's examination whether the state interference in the exercise of this right has in fact occurred. The resolution of the matter is essentially an analysis of the compatibility of the complaint with the provisions of the Convention, including the relevant conditions - ratione materiae, ratione temporis, ratione personae, ratione loci (KURDYUKOV, 2001, p. 104-119).

Citizens of the Russian Federation applying to the European Court for protection of the right to a healthy and favorable environment must take into account the important provision on the criteria to be met by complaints of violation of the right in question. Admissibility criteria for an individual complaint to the European Court of Human Rights are rudimentary formulated in Articles 34 and 35 of the Convention for the Protection of Human Rights and Fundamental Freedoms. It means that a complaint to the ECtHR can only be brought against a State (and in no way against individuals) in accordance with Art. 33, 34 of the Convention. Individuals acting in their personal capacity must not be confused with private individuals who are legally vested with certain functions of a public authority.

First criterion. Article 34 of the European Convention for the Protection of Human Rights and Fundamental Freedoms defines the range of persons entitled to lodge an individual complaint with the ECtHR.

The Court may receive applications from any person, non-governmental organization or group of individuals claiming to be the victim of a violation by one of the High Contracting Parties of the rights set out in the Convention or its Protocols. The High Contracting Parties undertake not to hinder in any way the effective exercise of that right.

Standing of applicants: first, the applicant cannot be a State, a state authority or any other type of public authority, including local government or municipal authorities. On the other hand, only a state that is a member of the Council of Europe and has signed and ratified the European Convention for the Protection of Human Rights and Fundamental Freedoms and that has violated the human rights and fundamental freedoms provided for in that Convention can be a defendant, and not any private person (individual or legal entity). Otherwise, the complaint may be declared inadmissible on the grounds of non-compliance with the ratione personae criterion. In that case, the aggrieved person will not be able to apply to the ECtHR for a violation of the right to a favorable environment, if the defendant is a large industrial plant.

Second criterion. The petitioner himself should be recognized as having status of victim under the European Convention for the Protection of Human Rights and Fundamental Freedoms. The European Court of Human Rights does not accept complaints filed on behalf of an indefinite number of persons by other natural or legal 
persons who are not themselves victims of a violation of the European Convention for the Protection of Human Rights and Fundamental Freedoms or are not authorized by them to bring a case before this Court. Relatives or acquaintances of victims not living with them may not bring a complaint on their own behalf before the ECtHR alleging violations by the State of the victim's rights to a healthy environment, such as noise from a highway or smoke from a restaurant in the basement. In the ECtHR practice, such inadmissible complaints are called "actio popularis". The European Court of Human Rights will also not accept complaints of possible future violations of rights, in particular legal disputes on compliance with the Convention.

The case law of the European Court of Human Rights also requires that the applicant not only be a real "victim" of a violation of the European Convention for the Protection of Human Rights and Fundamental Freedoms, but also that he or she remains so at all stages of the proceedings before that Court. For example, if the applicant alleged a violation of his or her rights by a nearby plant polluting the air with harmful emissions, but the violation had been rectified by the respondent State by the time the complaint was prepared for consideration, his complaint will be inadmissible on the merits in the European Court.

Third criterion. The European Court of Human Rights, in considering the admissibility of a complaint, takes into account the date of formal entry into force of the European Convention for the Protection of Human Rights and Fundamental Freedoms against the respondent State concerned. Time criterion means that a state, by signing and ratifying an international treaty, undertakes to fulfil it from a certain point in time. The Russian Federation undertook to respect the human rights stipulated in the European Convention for the Protection of Human Rights and Fundamental Freedoms since May 5, 1998. Thus, the Russian Federation is not responsible for the violations committed prior. However, there are exceptions to this rule in the Court's practice. In this connection, the pilot case "Burdov v. Russia", 2002 is remarkable. Despite the fact that the events at the Chernobyl NPP took place in 1986, the Court considered and found a violation of the Convention provision by Russia under Art. 6 (right to a fair trial), interpreting it as a continuing offense.

The following conditions for admissibility must be added: exhaustion of domestic remedies and the six-month rule (Article $35 \S 1$ of the Convention); abuse of the right of complaint (Article $35 \S 3$ of the Convention); previously submitted complaint to the Court or other international instances (Article $35 \S 2$ of the Convention); victim status (Article 34 of the Convention); lack of significant damage (Article $35 \S 3$ (b) of the Convention); manifestly ill-founded complaint (Article $35 \S 3$ of the Convention).

We should acknowledge, however, that the ECtHR has changed the system of 
The right to a balanced and healthful ecology in the legal framework of the European Convention of Human Rights and case law of the ECtHR

prioritization of cases ${ }^{52}$. In order for a complaint to be listed as "having impact", it must meet one of three criteria:

1. the case resolution "may modify or clarify international, domestic law or practice";

2. the case may involve "moral or social issues";

3. the case raises "a new or significant human rights issue".

In view of the new reform of the Court, the third criterion could give rise to priority consideration of a case before the ECtHR in "environmental cases".

However, there is no single list of criteria in the Convention, resulting in differences in the wording of both individual criteria and their system as a whole ${ }^{53}$ according to legal practitioners 54 .

\section{OVERVIEW OF THE EUROPEAN COURT OF HUMAN RIGHTS JURISPRUDENCE ON THE PROTECTION OF THE RIGHTS OF INDIVIDUALS AND GROUPS TO COMPLAIN FOR VIOLATIONS OF THEIR RIGHTS TO A HEALTHY AND FAVORABLE ENVIRONMENT}

So-called "environmental categories of cases" can be distinguished in the European Court of Human Rights, in which the poor environment (MALINOVSKY; OSINA; TRIKOZ, 2020) has harmful effects on human health. Such factors as the level of traffic noise ${ }^{55}$ and other noises ${ }^{56}$ (for example, night bars), pollution from industrial activities $^{57}$, industrial accidents ${ }^{58}$, contamination by hazardous wastes ${ }^{59}$, the release of

\footnotetext{
${ }^{52}$ See, The Court's Priority Policy. URL: https://www.echr.coe.int/documents/priority_policy_eng.pdf

${ }^{53}$ URL: https://www.echr.coe.int/Documents/COURtalks_Inad_Talk_RUS.PDF

${ }^{54} \mathrm{URL}$ : https:// europeancourt.ru/kriterii-priemlemosti-zhaloby-v-evropejskijsud/https://www.echr.coe.int/Documents/COURtalks_Inad_Talk_RUS.PDF

${ }^{55}$ Application no. 36022/97, Hatton and Others v. the United Kingdom, ECHR Judgment of 08 July 2003; Applications nos. 3675/04, 23264/04, Flamenbaum and Others v. France, ECHR Judgment of 13 December 2012; Application no. 2345/06, Deés v. Hungary, ECHR Judgment of 09 November 2010; Application no. 38182/03, Grimkovskaya v. Ukraine, ECHR Judgment of 21 July 2011; Application no. 50474/08, Bor v. Hungary, ECHR Judgment of 18 September 2013.

${ }^{56}$ Application no. 4143/02, Moreno Gómez v. Spain, ECHR Judgment of 16 of November 2004; Application no. 61260/08, Oluić v. Croatia, ECHR Judgment of 20 August 2010; Application no. 43449/02, Mileva and Others v. Bulgaria, ECHR Judgment of 25 November 2010; Application no. 3356/15, Zammit Maempel and Others v. Malta, ECHR Judgment of 15 January 2019.

${ }^{57}$ Application no. 16798/90, López Ostra v. Spain, ECHR Judgment of 09 December 1994, § 51 URL; Application no. 55723/00, Fadeyeva v. Russia, ECHR Judgment of 09 June 2005; Applications nos. 53157/99, 53247/99 and 56850/00, Ledyayeva, Dobrokhotova, Zolotareva and Romashina v. Russia, ECHR Judgment of 26 October 2006.; Application no. 30499/03, Dubetska and Others v. Ukraine, ECHR Judgment of 10 February 2011.

${ }^{58}$ Application no. 14967/89, Guerra and Others v Italy, ECHR Judgment of 19 February 1998.

${ }^{59}$ Application no. 59909/00, Giacomelli v. Italy, ECHR Judgment of 02 November 2006.
} 
unpleasant smells ${ }^{60}$, nuclear tests ${ }^{61}$ have been repeatedly considered by the Court in relation to the issue of the causal link between environmental pollution and the right to health. A new trend in the practice of the ECHR is the category of cases such as the harmful effects of greenhouse gas emissions on human health ${ }^{62}$. Nowadays, we witnessed the expansion of the concept of human rights interrelated to the right to health. Moreover, preservation of the environment is seen as one of the new functions of the state. For instance, it is the right to make solar energy on the property, without unreasonable interference by the utility or the government. In this case, ensuring the right to light (installation right) is directly related to human health. At the same time, solar energy must be legal or do not violate public health and safety.

In my view, the case law of the European Court of Human Rights on violations of the right to a healthy and favorable environment can be classified on various grounds:

1. on a legal basis (violation of Articles 2, 3, 6, 8, 13, 14 of the Convention);

2. by types of environmental pollution (excessive traffic noise and other noise, such as night bars; pollution from industrial activities; industrial accidents; pollution by hazardous wastes, contamination from nuclear tests);

3. by biological impact to nature and humans;

4. countries where violations of the provisions of the Convention have been found following the applicants' complaints.

The author of this article analyze the ECtHR legal positions on the right to a healthy and favorable (i.e. prosperous, clean, safe, quiet, calm, quality) environment by type of its pollution.

\subsection{APPLICATIONS ALLEGING EXCEEDING STANDARDS OF TRAFFIC AND OTHER NOISE}

The Grand Chamber of the European Court of Human Rights in "Hatton and Others v. the United Kingdom"63 case considered the increase in the number of night flights at Heathrow Airport, resulted in noise disturbing local residents. The Court

\footnotetext{
${ }^{60}$ Application no. 4143/02, Moreno Gómez v. Spain, ECHR Judgment of 16 of November 2004; Application no. 61260/08, Oluić v. Croatia, ECHR Judgment of 20 of August 2010; Application no. 43449/02, Mileva and Others v. Bulgaria, ECHR Judgment of 25 of February 2011; Application no. 3356/15, Zammit Maempel and Others v. Malta, ECHR Judgment of 10 of October 2017.

${ }^{61}$ Application nos. 21825/93, 23414/94, McGinley \& Egan v. the United Kingdom, ECHR Judgment of 09 June 1998; Application no. 14/1997/798/1001, L.C.B. v. The United Kingdom, ECHR Judgment of 9 June 1998; Application no. 32555/96, Roche v. The United Kingdom, ECHR Judgment of 19 October 2005.

${ }^{62}$ Application no. 39371/20, Duarte Agostinho and Others v. Portugal and 32 Other States.

${ }^{63}$ Application no. 36022/97, Hatton and Others v. the United Kingdom, ECHR Judgment of 08 July 2003.
} 
The right to a balanced and healthful ecology in the legal framework of the European Convention of Human Rights and case law of the ECtHR

found that there was an economic incentive in providing full-service night flights and only a small percentage of people were affected by the noise, that realty prices had not fallen, and that the applicants could move elsewhere without financial loss. Under these circumstances, the Court found that there was no violation of Article 8 as the authorities were within their discretion. In "Flamenbaum and Others v. France" ${ }^{164}$, the applicants complained about the noise caused by the extension of the main runway at the airport and the deficiencies in the relevant decision-making process. Assuming that the domestic courts had found the project to be in the public interest and the Government had made the economic well-being of the region a legitimate objective, and having regard to the measures taken by the authorities to limit the effects of noise; the Court held that a fair balance had been struck between the competing interests.

Moreover, the applicants were able to participate and comment at every stage of the French Government's decision-making procedure. Accordingly, no violation of Article 8 was found.

Unregulated heavy street traffic, causing serious noise, vibration and pollution was also the subject of complaints to the Court. In "Deés v. Hungary" ${ }^{\text {" }}$, the Court held that despite the authorities' efforts to restrict and reorganize traffic in the applicant's, he had suffered from excessive noise for an extended period. Consequently, the respondent State had failed in its positive obligation to guarantee his right to respect for private and family life, in violation of Article 8 of the Convention. In "Bor v. Hungary" applicant complained that the noise from a nearby railway station made his house almost uninhabitable. The Court found that the State had failed in its positive obligation to secure the applicant's right to respect for his home since national courts had been unable to settle the dispute properly for 16 years and to achieve a win-win situation for both parties to the dispute.

In "Yevgeniy Dmitriyev v. Russia" other inconveniences caused by the day-to-day activities of the police and temporary detention centers in the basement of his apartment building. He considered it to be an interference by the State with his right to respect for private and family life in violation of Article 8 of the Convention. The Court upheld the complaint in part and found a violation of Article 8 of the Convention.

Violations of Article 8 were also found with regard to persistent noise from a local nightclub, which seriously disturbed the applicant's sleep for a prolonged period ${ }^{68}$;

\footnotetext{
${ }^{64}$ Applications nos. 3675/04, 23264/04, Flamenbaum and Others v. France, ECHR Judgment of 13 December 2012.

${ }^{65}$ Application no. 2345/06, Deés v. Hungary, ECHR Judgment of 09 November 2010.

${ }^{66}$ Application no. 50474/08, Bor v. Hungary, ECHR Judgment of 18 September 2013.

${ }^{67}$ Application no. 17840/06, Yevgeniy Dmitriyev v. Russia, ECHR Judgment of 1 December 2020.

${ }^{68}$ Application no. 4143/02, Moreno Gómez v. Spain, ECHR Judgment of 16 November 2004.
} 
excessive noise at night and disturbance from a bar in the part of the house where the applicant lived ${ }^{69}$; and high levels of noise from an electronic games and computer club in the apartments adjacent to the applicants' home ${ }^{70}$. In each of these cases, it was found that the respondent State had failed to comply with its positive obligation to guarantee the applicants right to have their home and privacy respected. In "Zammit Maempel and Others v. Malta"71, the family complained that their lives and property had been endangered by allowing to set off firework outside their home twice a year. The Court found no violation of Article 8 since only minimal and reversible property damage occurred, there was no risk of injuries and some degree of protection had been provided by the State. It was also relevant that petitioners were fully aware of the situation when they purchased the property.

\subsection{APPLICATIONS ALLEGING INDUSTRIAL POLLUTION}

Where hazardous industrial activities affect the health and well-being of local residents, the Convention for the Protection of Human Rights and Fundamental Freedoms of 1950 imposes a positive obligation on the State to protect the health of people living close to the center of activities, to inform them of the harmful effects of the activities including any accidental risk, and to resettle them in a safe place, if necessary and possible. In "Fadeyeva v. Russia" the applicant's house was located in an area designated as a health protection zone because of its proximity to a large steel mill whose noise and industrial emissions were hazardous to health and well-being of the people living there. The Court held that although the Government had launched a resettlement program for people living in the sanitary protection zone and the applicant was on the waiting list for housing, she had not been offered any effective solution that would have helped her to move. Moreover, although the plant operated in violation of internal environmental standards, no effective measures have been taken to reduce the pollution to acceptable levels. Accordingly, there had been a violation of the applicant's rights to have her privacy and home respected under Article 8 of the Convention.

A similar observation was made in "Ledyayeva, Dobrokhotova, Zolotareva and Romashina v. Russia"73, where the State had not appropriately addressed the issue of applicants' protection from serious environmental hazards by relocating them from a contaminated area.

\footnotetext{
${ }^{69}$ Application no. 61260/08, Oluić v. Croatia, ECHR Judgment of 20 August 2010.

${ }^{70}$ Application no. 43449/02, Mileva and Others v. Bulgaria, ECHR Judgment of 25 November 2010.

${ }^{71}$ Application no. 3356/15, Zammit Maempel and Others v. Malta, ECHR Judgment of 15 January 2019.

${ }^{72}$ Application no. 55723/00, Fadeyeva v. Russia, ECHR Judgment of 09 June 2005.

${ }^{73}$ Applications nos. 53157/99, 53247/99 and 56850/00, Ledyayeva, Dobrokhotova, Zolotareva and Romashina v. Russia, ECHR Judgment of 26 October 2006.
} 
The right to a balanced and healthful ecology in the legal framework of the European Convention of Human Rights and case law of the ECtHR

In "Guerra and Others v. Italy" 74 , 150 local residents, including the applicants, were hospitalized with acute arsenic poisoning following an accident caused by faulty plant equipment. Appellants had not received essential information for several years that would enable them to assess the risks to which they and their families were exposed as they continued to live in the town, and which only became apparent in the accident at the plant. The court found that the State had failed in its affirmative obligation to provide the local community with information on risks and risk management options. The State thus had violated the applicants' right to respect for private and family life under Article 8 of the Convention.

In "Tătar v. Romania" ", a gold mine that used sodium cyanide in its mining process was located near the applicants' home. The accident released approximately 100,000 cubic meters of cyanide-contaminated water into the environment. The petitioners claimed that the incident caused their son's asthma to worsen. Although the applicants were unable to prove a causal link between exposure to sodium cyanide and their son's asthma, the Court found that the public authorities had not properly fulfilled their duty to assess the risks related to the company's activities and had failed to take appropriate measures to protect people's right to privacy and home, in particular their right to a healthy and safe environment.

In "Önerylldiz v. Turkey" authorization - on land surrounding a waste dump. In April 1994, there was a methane explosion and the waste discharged by the explosion covered more than ten houses, including the applicant's home. The Court noted that the authorities had failed to provide the residents with information about the risks to which they were exposed by living there, but the ECtHR further concluded that even if they had such information, the authorities were responsible because they had failed to take the necessary practical steps to avoid the risk to the lives of citizens.

\subsection{APPLICATIONS ALLEGING NEGLIGENCE OF THE AUTHORITIES RESULTING IN ENVIRONMENTAL ACCIDENTS}

In "Budayeva and Others v. Russia"77, the first applicant's husband was killed and she and other members of her family were injured in a landslide. The Court noted that the authorities had failed to implement a proper land management and emergency relief policy in light of the foreseeable risk of a landslide with devastating consequences in the

\footnotetext{
${ }^{74}$ Application no. 14967/89, Guerra and Others v Italy, ECHR Judgment of 19 February 1998.

${ }^{75}$ Application no. 67021/01, Tătar v. Romania, ECHR Judgment of 27 January 2009.

${ }^{76}$ Application no. 48939/99, Öneryld1z v. Turkey, ECHR Judgment of 30 November 2004.

${ }^{77}$ Applications nos. 67667/09, 44092/12 and 56717/12, Budayeva and Others v. Russia, ECHR Judgment of 20 March 2008, § 132.
} 
area. Funds were not allocated for urgent repairs, nor were important practical measures taken to ensure the safety of the local population. Consequently, there was a violation of Article 2 of the Convention. In "Kolyadenko and Others v. Russia"78, a flash flood caused by a state-owned company had endangered the applicants' lives and property. The authorities were aware that in the event of heavy rainfall it might be necessary to urgently drain the reservoir, causing widespread flooding. Despite this, they failed to prevent settlement of the area and to take effective measures to protect against flooding. The Court found that the State had failed in its obligation to protect the applicants' lives and that the national courts had failed to prosecute the officials or State authorities in violation of both the substantive and procedural parts of Article 2 of the Convention.

\subsection{APPLICATIONS ALLEGING WASTE POLLUTION, ODORS OR OTHER TYPES OF INTERFERENCE}

The Court has also applied the above principles to cases of pollution by hazardous waste. In "Giacomelli v. Italy" which concerned noxious emissions from the Special Waste Treatment Plant located approximately 30 meters from the claimant's house, the Court noted that there had been no environmental impact study, which under domestic law had to be completed before the plant could start working. Although the domestic courts had ordered that the plant be suspended until it was brought into compliance with environmental regulations, the facility had not been closed. There was a violation of Article 8 in these circumstances. In "Brânduşe v. Romania"80, the pungent odors from a garbage can in the vicinity of the applicant's prison cell had adversely affected his quality of life. In the present case, the ECtHR unanimously found a violation by Romania of Article 8 of the Convention, having ascertained, in particular, that although the applicant's health had not deteriorated due to being near the former dump, it must be noted that, given the findings of the above expert study as well as the length of time during which the applicant suffered from that inconvenience, his quality of life and well-being had been so affected that his privacy had been damaged which could not be considered merely as a consequence of imprisonment. The applicant's complaint referred to circumstances which went beyond the concept of detention within the meaning of Article 5 of the Convention as such, and which, moreover, concerned the only "living space" available to the applicant for several years.

\footnotetext{
${ }^{78}$ Applications nos. 17423/05, 20534/05, 20678/05, 23263/05, 24283/05 and 35673/05, Kolyadenko and Others v. Russia, ECHR Judgment of 28 February 2012.

${ }^{79}$ Application no. 59909/00, Giacomelli v.Italy, ECHR Judgement of 02 November 2006.

${ }^{80}$ Application no. 39951/08, Brânduşe v. Romania, ECHR Judgment of 27 October 2015.
} 
The right to a balanced and healthful ecology in the legal framework of the European Convention of Human Rights and case law of the ECtHR

In "Di Sarno and Others v. Italy" worked suffered a "waste crisis" and had been in a state of emergency for some 15 years. Garbage piled up in the streets for at least six months. The Court found that the authorities' long-standing failure to ensure the proper collection, processing and disposal of waste in the region violated the applicants' right to privacy and home in breach of Article 8 of the Convention.

\subsection{APPLICATION ALLEGING THE AUTHORITY'S INACTION RESULTING IN VIOLATIONS OF THE APPLICANTS' HEALTH RIGHTS DURING NUCLEAR AND CHEMICAL TESTING (NUCLEAR TESTS)}

According to the ECtHR, state-sponsored nuclear testing is a hazardous activity that can have hidden adverse effects on public health. For example, "McGinley $\mathcal{E}$ Egan v. the United Kingdom" ${ }^{82}$ involved former members of the British Army who were present during nuclear tests on Christmas Island in the 1950s. On the facts, the Court found that the applicants had been provided with sufficient information as to whether they had been exposed to hazardous levels of radiation during nuclear testing, and that the State had thereby complied with its positive obligation under Article 8 of the Convention. The case of "L.C.B. v. the United Kingdom" 83 involved the daughter of a soldier from Christmas Island. After developing leukemia, she complained about the authorities' failure to protect her health. The Court found that it was impossible to establish whether the applicant's father had actually been exposed to dangerous levels of radiation. Therefore, no causal link had been established between the father's possible exposure and the complainant's leukemia, so no violation of Article 2 of the Convention. In "Roche v. The United Kingdom" ${ }^{84}$, the applicant suffered serious health problems as a result of exposure to mustard gas and nerve gas during tests on him in the 1960s while he was serving in the British Army. The Court found that the respondent State had not provided the applicant with pertinent information allowing him to assess the risks he had been exposed to during his participation in the tests. There has, accordingly, been a violation of Article 8 of the Convention.

In the case law of the ECtHR, a new trend in the protection of collective rights to a quality environment should be noted. An example is the complaint "Duarte Agostinho

\footnotetext{
${ }^{81}$ Application no. 30765/08, Di Sarno and Others v. Italy, ECHR Judgment of 10 January 2012.

${ }^{82}$ Application nos. 21825/93, 23414/94, McGinley \& Egan v. the United Kingdom, ECHR Judgment of 09 June 1998.

${ }^{83}$ Application no. 14/1997/798/1001, L.C.B. v. The United Kingdom, ECHR Judgment of 9 June 1998.

${ }^{84}$ Application no. 32555/96, Roche v. The United Kingdom, ECHR Judgment of 19 October 2005.
} 
and Others v. Portugal and 32 Other States" ${ }^{85}$ pending in 2021 (no. 39371/20). The applicants complain about greenhouse gas emissions in 33 Contracting States of the Council of Europe. In their minds, such emissions contribute to global warming and cause, inter alia, heat waves that affect quality of life and health. The Court, for its part, notified the government of the complaint and prepared questions to the parties under Article 1 (jurisdiction of States), Article 2 (right to life), Article 3 (prohibition of inhuman or degrading treatment), Article 8 (right to privacy, family and inviolability of home), Article 14 (prohibition of discrimination) and Article 34 (individual complaints) of the Convention, as well as Article 1 (protection of property) of Protocol No 1 to the Convention.

\section{CONCLUSIONS}

The right to a healthy, sustainable and favorable environment is a fundamental right, the importance of which is vital due to the rapid technological development. One of the remarkable phenomena in the development of sciences is the rapid expansion of the new discipline of engineering in the last few decades. This new generation of "ecological" rights is increasingly moving towards this broader conception. It seems that the legal framework for long-term environmental cooperation among states is most fully codified informally. That is why it is important to adapt Global Pact for the Environment on universal level.

The jurisprudence of the European Court of Human Rights highlights the following important human rights aspects related to ecology and the environment:

1. The ECtHR and other international judicial organs consider justiciable such rights as the right to enjoy a healthy environment, to be aware of its conditions and challenges, eligibility for injury compensation and any abuses of these rights should be the basis of a complaint. As for the evolving concepts of right to a balanced and healthful ecology, right to availability of information about environmental conditions and challenges, right to reparation for injury to health, their practical implication should be legally enforceable under the international legislation and in case of nonimplementation of these rights an individual or a group should claim to be the victim of human rights abuses by a High Contracting Party, according to the relevant Convention or its Protocols and such violations are considered as the basis of a complaint.

2. The fundamental rule, which has a direct bearing to the reasons asserted

\footnotetext{
${ }^{85}$ Application no. 39371/20, Duarte Agostinho and Others v. Portugal and 32 Other States.
} 
The right to a balanced and healthful ecology in the legal framework of the European Convention of Human Rights and case law of the ECtHR

by the claimants for the so called "environmental cases" ${ }^{86}$ before the ECtHR, is Article 8 of the 1950 Convention for the Protection of Human Rights and Fundamental Freedoms. An affected State still can be held accountable for a specific alleged violation although it does not always retain primary responsibility. Inaction on the part of a State regarding the protection of privacy and failure in developing of all possible (not only mandatory) appropriate responses that would have prevented or eliminated the environmental hazard, is sufficient to entail the responsibility of the State. It is therefore repeatedly underscored by the ECtHR that a State must not face up to its responsibilities in all cases of refusal to resettle citizens in an environmentally friendly area or to compensate for refusal to resettle. Implementation of state-owned infrastructure projects can add further complications but such projects have a public interest, which tends to exceed the private interest. Nevertheless, it is vital to balance interests as well as to provide information and enhance awareness and citizen's engagement in public policy debates and project development within a harmminimization environment. The application of Articles 2, 3, 6, 8, 13, 14 of the Convention was well illustrated in international practice and was likewise predicated on the case law of the ECtHR regarding allegations of violations of rights for health-friendly environment committed against individuals and groups.

3. Cases of environmental rights violations are complicated in terms of preparing a complaint and processing by the ECtHR. A further reason, related to the above, is that most evidence can only be obtained from the state authorities and such information and documents are not always available or cast doubt on their veracity. Damage to life or health is easy to prove, but it is hard to do so with regard to the causal link between the acts (omission) of state agencies, the violation of environmental rights and the consequences that occurred.

4. On European level, particularly, Article 8 of the Convention applies in environmental cases where the pollution is directly attributable to the State or where State liability arises because of the failure to regulate the private sector properly. In view of the new reform of the ECtHR, the third criterion named "a new or significant human rights issue" could give rise to priority consideration of "environmental cases".

Finally, as the Convention does not explicitly address environmental rights, each specific situation and circumstances call for a strictly individual approach to review and qualification. Case law allows for reliance on established practice, but this is not always possible because environmental conditions and national legislation of different countries has undergone significant changes over time, and, therefore, the Court should respect these circumstances and create new precedents. This is evidenced, inter alia, by

\footnotetext{
${ }^{86}$ Application no. 36022/97, Hatton and Others v. the United Kingdom, ECHR Judgment of 08 of July 2003; Application no. 16798/90, López Ostra v. Spain, ECHR Judgment of 09 December 1994; Application no. 55723/00, Fadeyeva v. Russia, ECHR Judgment of 09 of June 2005.
} 
an unprecedented case - for the first time in the history of ECtHR case law, a complaint was filed by six young Portuguese companies alleging inaction on the part of 33 European states on climate change, global warming and environmental degradation in the territory of the Council of Europe. This fact clearly illustrates the growing public concern for the future of the planet.

\section{REFERENCES}

ANISIMOV, I. O.; GULYAEVA, E. E. Promoting the development and transfer of marine technologies as a mechanism for implementing the sustainable develoment goals: international legal aspect. Revista Opinião Juridica, Fortaleza, v. 19, n. 32, p. 184201, 2021.

BHUTA, Nehal. The Frontiers of Human Rights. Extraterritoriality and its Challenges. Oxford: Oxford University Press, 2016.

CHURKINA, L. M.; BELYAEV, S. I. Right to life, prohibition of torture and inhuman or degrading treatment or punishment: European standards, Russian legislation and law-enforcement practice. Yekaterinburg: [s.n.], 2005. p. 24-37.

CONFORTI, B. Exploring the Strasbourg Case-Law: Reflection on State Responsibility for the Breach of Positive Obligations. In: FITZMAURIS, M.; SAROOSHI, D. (ed.). Issues of State Responsibility Before International Judicial Institutions. Oxford: Hart Publishing, 2004. p. 129-137.

CONSTITUTION of the Russian Federation, Art. 41 Part 1 (Adopted by popular vote 12.12.1993) (taking into account the amendments introduced by the Laws of the Russian Federation on amendments to the Constitution of the Russian Federation of 30.12.2008 № 6-FCL, of 30.12.2008 № 7-FCL, of 05.02.2014 № 2-FCL, of 21.07.2014 № 11-FCL, of 11.03.2020 №1 FCL) // C3 RF, 16 March 2020 № 11, article 1416.

COUNCIL OF EUROPE. Manual on Human Rights and the Environment. Council of Europe Publishing. Strasbourg, 2006. Available in: https://www.echr.coe.int/Documents/Pub_coe_Environment_2012_ENG.pdf. Accessed: 10 Apr. 2021.

DECREE of the President of the Russian Federation "On reduction of greenhouse gas emissions" № 666 of November 4, 2020. Available in: http://www.kremlin.ru/acts/bank/45990. Accessed on: 10 Apr. 2021.

DUPUY, P. M. International Environmental Law. Cambridge: Cambridge University Press, 2015. 
The right to a balanced and healthful ecology in the legal framework of the European Convention of Human Rights and case law of the ECtHR

DUPUY Pierre-Marie; VIÑUALES, Jorge Enrique. Introduction au droit international de l'environnement. [S.l.: s.n.], 2015.

DUVIC-PAOLI, L. A. The Status of the Right to Public Participation in International Environmental Law: an analysis of the jurisprudence. Yearbook of International Environmental Law, v. 23, n. 1, p. 80-105, 2012.

DUVIC-PAOLI, L. A. The Prevention Principle in International Environmental Law. Cambridge: Cambridge University Press, 2018.

DUVIC-PAOLI, L. A. Environmental Law and Public International Law. In: Lees, E.; VINUALES, J. (ed.). The Oxford Handbook of Comparative Environmental Law. Oxford: Oxford University Press, 2019.

DWORKIN, Ronald. "Policy” and “Principles”. Praha: Oikoymenh, 2001.

ENVIRONMENTAL Doctrine of the Russian Federation approved by decree of the Government of the Russian Federation dated August 31, 2002, № 1225-r.

EUROPEAN Charter of Fundamental Rights of 2000. New Delhi Declaration on the Principles of International Law Related to Sustainable Development of 2002. Available in: https://www.ecolex.org/details/literature/new-delhi-declaration-of-principles-ofinternational-law-relating-tosustainable-development-mon-070850/. Accessed: 10 Apr. 2021.

EUROPEAN COMMISSION. Official website of EU towards EU environmental priorities and targets. Available in: https://ec.europa.eu/environment/index_en. Accessed: 10 Apr. 2021.

EUROPEAN COURT OF HUMAN RIGHTS. Convention for the Protection of Human Rights and Fundamental Freedoms of 1950. Available in: https://www.echr.coe.int/Documents/Collection_Convention_1950_ENG.pdf. Accessed: 10 Apr. 2021.

GAETA, Paola; VIÑUALES, Jorge E.; ZAPPALÁ, Salvatore. Cassese's International Law. 3th ed. [S.l.: s.n.], 2020.

GOMIEN, D. Short Guide to the European Convention on Human Rights. 3th ed. Strasbourg: [s.n.], 2005. p. 16-19.

GUTERRES, António. Secretary-General's address at Columbia University: "The State of the Planet". New York, 2 Dec. 2020. Available in: https://www.un.org/sg/en/content/sg/speeches/2020-12-02/address-columbiauniversity-the-state-of-the-planet. Accessed: 10 Apr. 2021. 
KAPUSTIN, A. Y. Political-legal implications of EU politics remolding on international scene after the Reform Treaty comes into force. What internal and external EU politics will be after Lisbon Treaty coming into force (Materials of international conference, held in MGIMO (U) of MFA of Russia on February 22, 2008). M., 2008. p. 111.

KNOX, John H.; PEJAN, Ramin (ed.) The Human Right to a Healthy Environment. [S.l.: s.n.], 2018.

KURDYUKOV, D.G. Individual complaint in the context of the European Convention for the Protection of Human Rights and Fundamental Freedoms of 1950. Voronezh: [s.n.], 2001. p. 104-119.

LIPKINA, N. N. Legal positions of the European Court of Human Rights concerning the States' margin of appreciation in interference with rights and fundamental freedoms: doctoral dissertation. Candidate of Legal Sciences: 12.00.10. Moscow, 2008. p. 8.

MALINOVSKY, A.; OSINA, D.; TRIKOZ, E. Legal instruments for stimulating environmentally friendly behavior: successful practices in Russia and abroad. E3S Web of Conferences, v. 164, n. 1, p. 1-11, 2020. Available in: https://www.e3sconferences.org/articles/e3sconf/abs/2020/24/e3sconf_tpacee2020_1 1039/e3sconf_tpacee2020_11039.html. Access: 10 Apr. 2021.

MAY, James R.; DALY, Erin (ed.). Human Rights and the Environment. Legality, Indivisibility, Dignity and Geography. Elgar Encyclopedia of Environmental Law series. [S.l.]: Elgar, 2019.

SEGGER, Marie-Claire Cordonier; SAITO, Yolanda; WEERAMANTRY, Judge C.G. Sustainable Development Principles in the Decisions of International Courts and Tribunals: 1992-2012. [S.l.: s.n.], 2017.p. 884.

SOLNTSEV, A. M. Protection of Ecological Human Rights: Textbook. 2th ed. [S.l.]: PFUR, 2015.

STARMER, K. Positive Obligations under the Convention. In: JOWELL, J.; COOPER, J. (ed.). Understanding Human Rights Principles. Oxford: Hart Publishing, 2001. p. 139-159.

TRIKOZ, Elena; GULYAEVA, Elena. Ecological cases of the ECtHR and the environmental risks of GMO. E3S Web Conf., v. 244, 2021. XXII International Scientific Conference Energy Management of Municipal Facilities and Sustainable Energy Technologies (EMMFT-2020). Available in: https://www.e3s 
The right to a balanced and healthful ecology in the legal framework of the European Convention of Human Rights and case law of the ECtHR

conferences.org/articles/e3sconf/abs/2021/20/e3sconf_emmft2020_12024/e3sconf_e mmft2020_12024.html. Accessed: 10 Apr. 2021.

TUMANOV, V. A. The European Court of Human Rights: an outline of organization and activity. [S.l.: s.n.], 2001. p. 109-111.

TURNER, Stephen J. et al. (ed.). Environmental Rights: the development of standards. Delaware: Widener University School of Law, 2019.

UNITED NATIONS. Department of Economic and Social Affairs. Sustainable Development. Draft International Covenant on Environment and Development Implementing Sustainability - Fifth Edition. 2015. Available in: https://sustainabledevelopment.un.org/. Accessed: 10 Apr. 2021.

UNITED NATIONS TREATY COLLECTION. Paris Climate Agreement 2015. Available in: https://treaties.un.org/Pages/ViewDetails.aspx?src=TREATY\& $m$ tdsg_no=XXVII-7d\& chapter=27\&clang=_en. Accessed: 10 Apr. 2021.

UN Sustainable Development Goals - 2030. Available in: https://sdgs.un.org/goals. Accessed: 10 Apr. 2021.

VASAK, K. Les problèmes spécifiques de la mise en oeuvre des droits économiques et sociaux de l'homme. Université Catholique de. Centre d'études européennes. Vers une protection éfficace des droits économiques et sociaux. Deuxième colloque de Département des droits de l'homme. Louvian, Vander, 1973. p. 11-34.

VIÑUALES, Jorge E. The UN Friendly Relations Declaration at 50: an assessment of the fundamental principles of international law. Cambridge: University of Cambridge, 2020.

\section{JURISPRUDENCE OF THE INTERNATIONAL COURT OF JUSTICE AND THE EUROPEAN COURT OF HUMAN RIGHTS}

1. Case Concerning the Gabčíkovo-Nagymaros Project (Hungary/Slovakia) (1997), I.C.J. Rep. 7.

2. Advisory Opinion on the Legality of the Use by a State of Nuclear Weapons in Armed Conflict, Advisory Opinion, [1996] ICJ Rep. 226 at 438.

3. Certain Phosphate Lands in Nauru (Nauru/Australia) (1993), I.C.J. Rep. 322.

4. Application no. 36022/97, Hatton and Others v. the United Kingdom, ECHR Judgment of 08 of July 2003.

5. Application no. 16798/90, López Ostra v. Spain, ECHR Judgment of 09 December 1994, § 51 . 
6. Application no. 55723/00, Fadeyeva v. Russia, ECHR Judgment of 09 June 2005, § 69.

7. Application no. 14/1997/798/1001, L.C.B. v. The United Kingdom, ECHR Judgment of 9 June 1998.

8. Applications nos. 17423/05, 20534/05, 20678/05, 23263/05, 24283/05 and 35673/05, Kolyadenko and Others v. Russia, ECHR Judgment of 09 of July 2012.

9. Application no. 60272/00, Estamirov and others v. Russia, ECHR Judgment of 12 October 2006, § 118.

10. Applications nos. 57942/00 and 57945/00, Khashiev and Akayeva v. Russia, ECHR Judgment of 24 February 2005, § 153.

11. Application no. 77617/01, Mikheyev v. Russia, ECHR Judgment of 26 January 2006, § 104.

12. Application no. 67667/09, 44092/12 and 56717/12, Budayeva and Others v. Russia, ECHR Judgment of 20 June 2017, § 132.

13. Application no. 2345/06, Deés v. Hungary, ECHR Judgment of 09 November 2010.

14. Application no. 38182/03, Grimkovskaya v. Ukraine, ECHR Judgment of 21 July 2011.

15. Application no. 17840/06, Yevgeniy Dmitriyev v. Russia, ECHR Judgment of 1 of December 2020.

16. Application no. 30499/03, Dubetska and Others v. Ukraine, ECHR Judgment of 10 February 2011.

17. Application no. 14967/89, Guerra and Others v Italy, ECHR Judgment of 19 February 1998;

18. Application no. 67021/01, Tătar v. Romania, ECHR Judgment of 27 January 2009.

19. Application nos. 21825/93, 23414/94, McGinley \& Egan v. the United Kingdom, ECHR Judgment of 9 June 1998.

20. Application no. 4143/02, Moreno Gómez v. Spain, ECHR Judgment of 16 November 2004.

21. Application no. 43449/02, Mileva and Others v. Bulgaria, ECHR Judgment of 25 February 2011.

22. Application no. 9310/81, Powell and Rainer v. United Kingdom, ECHR Judgment of 21 February of 1990.

23. Application no. 48939/99, Öneryıldız v. Turkey, ECHR Judgment of 30 November 2004.

24. Application no. 59498/00, Burdov v. Russia, ECHR Judgment of 7 May 2002.

25. Application no. 41302/02, Malinowski v. Russia, ECHR Judgment of 7 July 2005.

26. Application no. 63973/00, Androsov v. Russia, ECHR Judgment of 6 October 2005.

27. Application no. 27440/03, Finkov v. Russia, ECHR Judgment of 8 October 2009. 
The right to a balanced and healthful ecology in the legal framework of the European Convention of Human Rights and case law of the ECtHR

28. Applications nos. 3675/04, 23264/04, Flamenbaum and Others v. France, ECHR Judgment of 13 December 2012.

29. Applications nos. 53157/99, 53247/99 and 56850/00, Ledyayeva, Dobrokhotova, Zolotareva and Romashina v. Russia, ECHR Judgment of 26 October 2006.

30. Application no. 30499/03, Dubetska and Others v. Ukraine, ECHR Judgment of 10 February 2011.

31. Application no. 59909/00, Giacomelli v. Italy, ECHR Judgment of 02 November 2006.

32. Application no. 61260/08, Oluić v. Croatia, ECHR Judgment of 20 August 2010.

33. Application no. 3356/15, Zammit Maempel and Others v. Malta, ECHR Judgment of 10 October 2017.

34. Application nos. 21825/93, 23414/94, McGinley \& Egan v. the United Kingdom, ECHR Judgment of 09 June 1998.

35. Application no. 32555/96, Roche v. The United Kingdom, ECHR Judgment of 19 October 2005.

36. Application no. 39371/20, Duarte Agostinho and Others v. Portugal and 32 Other States. Pending Case of ECHR. URL: https://www.nhri.no/wpcontent/uploads/2020/11/DUARTE-AGOSTINHO-and-others-vs-PORTUGALand-32-others-unofficial-translation-fr.en_.pdf (accessed: 10.04.2021).

37. Application no. 50474/08, Bor v. Hungary, ECHR Judgment of 18 September 2013.

38. Application no. 17840/06, Yevgeniy Dmitriyev v. Russia, ECHR Judgment of 1 December 2020.

39. Application no. 39951/08, Brânduşe v. Romania, ECHR Judgment of 27 October 2015.

40. Application no. 30765/08, Di Sarno and Others v. Italy, ECHR Judgment of 10 January 2012.

\section{Como citar este documento:}

GULYAEVA, Elena Evgenyevna. The right to a balanced and healthful ecology in the legal framework of the European Convention of Human Rights and case law of the ECtHR. Revista Opinião Jurídica, Fortaleza, v. 20, n. 33, p. 103-134, jan./abr. 2022. 